\title{
Vinegar rice (Oryza sativa L.) produced by a submerged fermentation process from alcoholic fermented rice
}

\author{
Wilma Aparecida SPINOSA ${ }^{1 *}$, Vitório dos SANTOS JÚNIOR ${ }^{1}$, Diego GALVAN ${ }^{1}$,

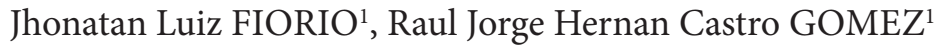

\begin{abstract}
Considering the limited availability of technology for the production of rice vinegar and also due to the potential consumer product market, this study aimed to use alcoholic fermented rice (rice wine (Oryza sativa L.)) for vinegar production. An alcoholic solution with $6.28 \%(\mathrm{w} / \mathrm{v})$ ethanol was oxidized by a submerged fermentation process to produce vinegar. The process of acetic acid fermentation occurred at $30 \pm 0.3^{\circ} \mathrm{C}$ in a FRINGS ${ }^{\circledR}$ Acetator (Germany) for the production of vinegar and was followed through 10 cycles. The vinegar had a total acidity of $6.85 \%(\mathrm{w} / \mathrm{v}), 0.17 \%$ alcohol $(\mathrm{w} / \mathrm{v}), 1.26 \%(\mathrm{w} / \mathrm{v})$ minerals and $1.78 \%(\mathrm{w} / \mathrm{v})$ dry extract. The composition of organic acids present in rice vinegar was: cis-aconitic acid $(6 \mathrm{mg} / \mathrm{L}), \mathrm{maleic}$ acid $(3 \mathrm{mg} / \mathrm{L})$, trans-aconitic acid ( $3 \mathrm{mg} / \mathrm{L})$, shikimic + succinic acid $(4 \mathrm{mg} / \mathrm{L})$, lactic acid (300 mg/L), formic acid (180 mg/L), oxalic acid $(3 \mathrm{mg} / \mathrm{L})$, fumaric acid $(3 \mathrm{mg} / \mathrm{L})$ and itaconic acid $(1 \mathrm{mg} / \mathrm{L})$.
\end{abstract}

Keywords: submerged fermentation; microfiltration; acetic acid bacteria; vinegar.

Practical Application: Vinegar rice produced by a submerged fermentation process from alcoholic fermented rice.

\section{Introduction}

Vinegar is a product used worldwide. Despite its still unknown origin, vinegar is now familiar to diverse cultures, and is consumed indiscriminately by all social classes. It is used as a condiment, for flavoring, as a preservative, as a medicine for routine use, and even as a cleaning agent (Qiu et al., 2010; Budak et al., 2014; Haruta et al., 2006; Baena-Ruano et al., 2006).

Rice vinegar and vinegar produced from other raw materials are widely used by Asian populations (Chen \& Chen, 2009; Xiao et al., 2011). In Japan, the acceptance of the product has reached the point where shops and bars specialize in commercial vinegar, even using refinements usually reserved for other products, such as aging in wooden casks (Haruta et al., 2006; Nakamura et al., 2010). As in the Japanese market, the established presence of vinegar in China has also led to the search for alternatives to trade the product, such as the launch of beverages with functional appeal based on rice vinegar (Chen \& Chen, 2009; Chen et al., 2012; Fan et al., 2009).

In Europe, where vinegar also assumes other functions, i.e. as a disinfectant, degreaser and odor neutralizer, per capita consumption reaches 1.8 L/year (Budak et al., 2014; Blankart, 2013). In Brazil, although less widespread and generally restricted to use as a seasoning, vinegar consumption is rooted in the culture of the country; the average Brazilian consumes $0.8 \mathrm{~L} /$ year (Blankart, 2013; Solieri \& Giudici, 2009). The use of vinegar in Brazil has increased, due to the increase in purchasing power, which has fostered the presence of imported vinegars, mainly from European countries. In the last decade, the competitive landscape has led most companies to offer special vinegars to the market (Rizzon \& Miele, 1998; Bortolini et al., 2001).

There are three main processes for the microbiological conversion of a dilute solution of ethanol (wine) in vinegar: the slow process (Orleans or French), the rapid process (or German) and the submerged process (Budak et al., 2014; Mas et al., 2014).

The term "submerged acetic fermentation" is analogous to the usual procedures involved in antibiotic production and the cultivation of yeasts. In this case, bacteria execute fermentative work on a fluid, which is the alcohol mixture. This is accomplished without contact material, such as wood chips or coal, which are used in processes with generators (the rapid process). Bacteria are always submerged in the liquid to ferment, where they multiply and oxidize the alcohol mixture into vinegar (Budak et al., 2014; Mas et al., 2014; Schlepütz et al., 2013).

In this process, acetic acid bacteria are submerged in the liquid to ferment, multiplying and drawing power from the oxidation of ethanol to acetic acid. To catalyze the reaction that gives them energy, acetic acid bacteria require an adequate and continuous supply of oxygen in all parts of the tank. An interruption in the oxygen supply, especially in the final stages of fermentation, will affect the performance (Budak et al., 2014; Mas et al., 2014). In view of the favorable consumption of vinegar, this work invested in an alternative for the production of rice vinegar by submerged fermentation. 


\section{Materials and methods}

\subsection{Rice vinegar}

The rice wine (Oryza sativa L.) used for vinegar production had an alcohol concentration of $6.28 \mathrm{~g} / 100 \mathrm{~mL}$, density $20^{\circ} / 20^{\circ} \mathrm{C}$ of 0.9890 , glucose content of $2.8 \mathrm{~g} / 100 \mathrm{~mL}$ and the $\mathrm{pH}$ was 3.00 .

\subsection{Microorganism Acetobacter sp}

In the fermentation step, Acetobacter sp, obtained from the company Frings Microdyn of Brazil (Piracicaba-SP), consisting of the natural contaminant alcoholic musts, were used in the presence of air. Such bacteria are selected spontaneously, depending on the acidity conditions of the medium in which they are kept.

\subsection{Acetic fermentation}

The Acetator ${ }^{\circledR}$ (Frings, Germany), used for rice vinegar production in submerged fermentation at the pilot scale, was obtained from Frings Microdyn of Brazil. The total volume of the Acetator ${ }^{\circledR}$ is $8.0 \mathrm{~L}$, with working volume of $6.0 \mathrm{~L}$, consisting of a transparent reaction vessel with cooling coils and turbine aeration, a foam rupture disc, probes for temperature measurement and manometry, and valves to control loading, unloading and cooling. The equipment has a height two times greater than its diameter. Inside the reactor, there is a cooling coil, whose function is to dissipate the heat generated by the exothermic reaction of fermentation and heat transfer from the motion of the aerator motor. The cooling water of the reactor is controlled by instrumentation to maintain a temperature oscillation of $\pm 0.3^{\circ} \mathrm{C}$ (Qi et al., 2014).

During the process, the total acidity, alcohol content and aeration were managed, as the acidity and alcohol content are the determining parameters for loading and unloading the fermentation cycles. The total concentration (TC) of the wine was given by the sum of the concentrations of ethanol and the total acidity (Adams \& Moss, 2008). Starting with 3.4 L of wine, with an alcohol content of $6.28 \%(\mathrm{w} / \mathrm{v})$, plus a $1.6 \mathrm{~L}$ inoculum of Acetobacter sp, this contained a mass of $2.7 \mathrm{~g} / \mathrm{L}$ of bacteria determined by measuring the optical density at $600 \mathrm{~nm}$.

The wine fermentation process was followed for 10 cycles. The submerged acetic fermentation process was conducted as a fed batch. When the alcohol content approached $0.5 \%, 1 / 3$ of the vinegar volume was withdrawn from the reactor and the same volume of wine was added.

The rice wine was adjusted to $0.5 \mathrm{~g} / \mathrm{L}$ nutrient salts. The composition of salts and mineral nutrients included diammonium phosphate, potassium sulfate, magnesium sulfate, concentrated bacterial growth factors and vitamins. The fermentation temperature was set at $30 \pm 0.3^{\circ} \mathrm{C}$ and was automatically controlled by the equipment. The air flow rate was maintained at around $30 \mathrm{~L} / \mathrm{h}$. The alcohol content was determined at the beginning and at the end of each fermentation cycle, while the acetic acid content was monitored at shorter intervals.

The velocity control of transformation of alcohol into acetic acid allowed the programming time of unloading and reloading of the automatic Acetator ${ }^{\circledR}$, so that the alcohol content was not less than $0.2 \%(\mathrm{w} / \mathrm{v})$. The relationship between the amount of mash fermentation removed and that remaining in the Acetator ${ }^{\circledR}$ was $1 / 3: 2 / 3$, thus maintaining the highest degree of acidity and avoiding too little alcohol.

\subsection{Vinegar filtration}

The system for crossflow microfiltration was composed of microporous polypropylene tubes with size of $0.2 \mu \mathrm{m}$. The capillary diameter was between 1.8 and $2.6 \mathrm{~mm}$. The tubes were bonded in modules and the surface of the membrane filter was $0.04 \mathrm{~m}^{2}$.

The vinegar not filtered was pumped continuously and recirculated inside the capillaries. Only a small portion of fluid crossed the membrane wall of the capillaries, leaving the module free of the bacteria contained in the crude vinegar.

\subsection{Yield}

The yield of acetic acid $\left(\eta_{\mathrm{aa}}\right)$ was calculated as the ratio of the mass of acetic acid produced $(\mathrm{g} / 100 \mathrm{~mL})$ and initial ethanol $(\mathrm{g} / 100 \mathrm{ml})$. The stoichiometric yield in the conversion of ethanol to acetic acid is 0.77 . The productivity of acetic acid $\left(\mathrm{P}_{\mathrm{aa}}\right)$ was calculated according to Equation 1.

$P_{a a}=\frac{\left(v_{a a} \text { produced }(L) x \text { content of aa }(g / L)\right)}{(\text { reactor volume }(L) x \text { fermentation time of the cycle }(h))}$

\subsection{Analytic methods}

The alcohol content ( $\% \mathrm{v} / \mathrm{v})$ was determined using a digital densimeter (Anton Paar, Austria, model DMA4500M). The total acidity was determined by titration with $0.1 \mathrm{M}$ sodium hydroxide and an alcoholic solution of phenolphthalein as the indicator (Brasil, 2005).

The volatile compounds present in rice wine used as raw material for the manufacture of vinegar were determined by gas chromatography with flame ionization (GC-FID) (Agilent, United States, Model 6890). A DBWAX column was used (30 m by $0.25 \mathrm{~mm}$ with a film thickness of $0.25 \mathrm{~mm}$ ). The column temperature was $120^{\circ} \mathrm{C}$ and the detector temperature was $200^{\circ} \mathrm{C}$. $\mathrm{N}_{2}$ was used as the carrier gas with a flow of $20 \mathrm{~mL} / \mathrm{min}$.

For the characterization of rice vinegar, the dry contents obtained at $100^{\circ} \mathrm{C}$ and the ash extract were assessed by the methodology prescribed by Brazilian law (Brasil, 2005). The analysis of these organic acids was based on the use of high performance liquid chromatography (HPLC) (Agilent, United States, Model 1050). A Bio-Rad Aminex (HPX-87H) column was used for organic acids, with dimensions of $300 \mathrm{~mm}$ by $7.8 \mathrm{~mm}$. The mobile phase was $5 \mathrm{mM}$ sulfuric acid, the injection volume was $20 \mu \mathrm{L}$ at a temperature of $55^{\circ} \mathrm{C}$ and the detector used was of refractive index.

\section{Results and discussion}

The rice wine used as a substrate for acetic fermentation showed fractions of esters, ketones, alcohols and aldehydes; these are shown in Table 1.

Aldehydes, ketones and alcohols are limiting factors in the inhibition of Acetobacter sp. In the submerged fermentation process, acetic acid bacteria have the ability to adapt smaller with inhibiting agents than those of the rapid acidification process. The industry standard recommends that the amounts of esters such as ethyl acetate in the alcohol to be used for acetic 
Table 1. Characterization of the rice wine used as a substrate for acetic acid fermentation.

\begin{tabular}{cc}
\hline Determination & $\mathrm{mg} / 100 \mathrm{~mL}$ \\
\hline Acetal & 1.38 \\
Acetaldehyde & 16.70 \\
Ethyl acetate & 0.05 \\
Acetone & 0.30 \\
Ethanol & 5592.24 \\
Glycerol & 650.00 \\
Isoamylic & 30.80 \\
Isobutanol & 4.78 \\
Methanol & 0.05 \\
$n$-Butanol & 0.05 \\
$n$-Propanol & 2.08 \\
\hline
\end{tabular}

fermentation should not exceed $0.2 \mathrm{~g} / 100 \mathrm{~mL}$, and methanol should not be present at levels greater than $0.035 \mathrm{~g} / 100 \mathrm{~mL}$ (Fortes et al., 2012; Reddy et al., 2008). These compounds have an inhibitory effect on acetic acid fermentation. Furthermore, methanol is toxic when present at levels above this level in fermented drinks (Dato et al., 2005). Glycerol was at a relatively low concentration $(0.65 \mathrm{~g} / 100 \mathrm{~mL})$, which is a negative aspect, since this compound gives the wine a soft and sweet taste when in the range of 7-9 $\mathrm{g} / \mathrm{L}$ (Clarke \& Bakker, 2008).

The results concerning acetic acid fermentation for each cycle are listed in Table 2. Columns 2 to 7 show the parameters of the feeding of each cycle. The others are related to the volume of the product and its features.

From the second cycle onwards, the fermentation process was stable regarding the time of fermentation, the acetic acid content in the product, yield and productivity. All averages were calculated neglecting the first cycle. It can be inferred that this type of fermentation, i.e. fed batch and using an automatic Acetator ${ }^{\circledR}$, provided satisfactory performance for the production of vinegar.

Figure 1 shows the total acidity in the vinegar obtained from the fermentation process from the second to the tenth cycle. The average value of total acidity of the vinegar obtained from the second to the tenth cycle was $7.11 \pm 0.35 \%$, expressed as acetic acid $(w / v)$, with a variation coefficient of 0.05 .

The acetic acid concentration in the fermented product varied from 6.6 to $7.8 \%(\mathrm{w} / \mathrm{v})$. This value indicates a high rate of conversion of ethanol to acid, as the substrate (rice wine) had an alcohol concentration of $6.28 \%(\mathrm{w} / \mathrm{v})$. The product meets the minimum requirements established by Brazilian law, which defines vinegar as having a minimal volatile acidity of $4 \mathrm{~g} / 100 \mathrm{~mL}$, expressed as acetic acid (Brasil, 2009). This value indicates that the product can almost be classified as double vinegar, where the fermented alcoholic vinegar must provide a volatile acidity exceeding $8 \mathrm{~g}$ of acetic acid per $100 \mathrm{~mL}$ of the product (Brasil, 2012).

The rice wine used as a raw material for rice vinegar had a $\mathrm{pH}$ of 3.0, while the average $\mathrm{pH}$ of the product amounted to $2.66 \pm 0.05$ with a variation coefficient of 0.02 , from the second to the tenth cycle of fermentation (Figure 2). Tessaro et al. (2010), in a fermented orange process, worked with orange wine with a

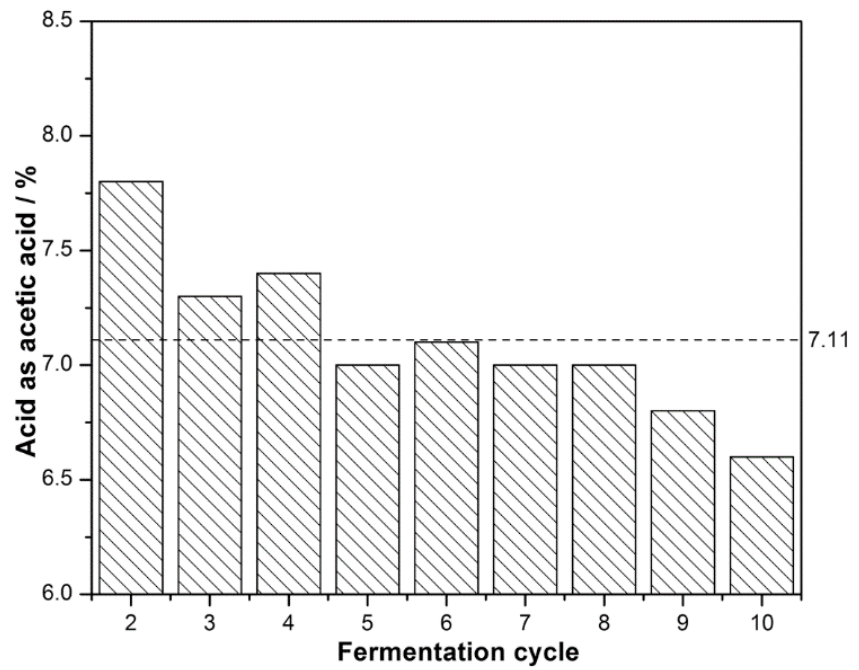

Figure 1. Total acidity of the rice vinegar fermented in the Acetator ${ }^{\circledR}$.

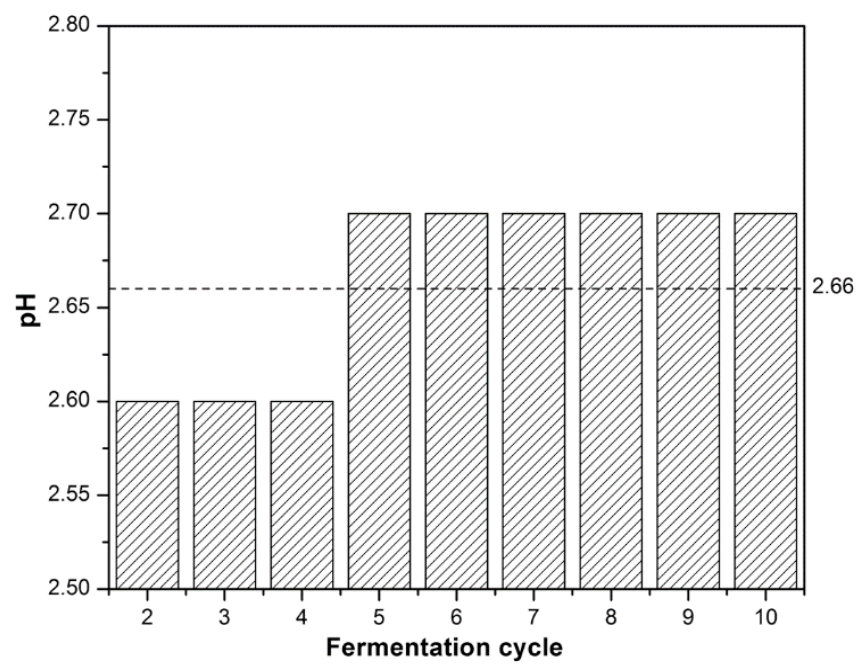

Figure 2. $\mathrm{pH}$ of rice vinegar fermented in the Acetator ${ }^{\circledR}$.

$\mathrm{pH}$ from 3.55 to 3.68. Bortolini et al. (2001) reported $\mathrm{pH}$ values for kiwi wine close to 3.6. According to Adams (1998), acetic acid levels of $7 \%$ in the vinegar give a $\mathrm{pH}$ value close to 3 .

In this study, the average time for the acetification of rice wine was $28.8 \pm 6.28 \mathrm{~h}$, with a coefficient of variation of 0.22 , to achieve an average total acidity of $7.1 \%$ acetic acid $(w / v)$. The process for the production of vinegar by submerged culture was capable of fermenting the alcohol substrate thirty times faster than any other process (fast or slow) (Moretto, 1988).

This rapid fermentation was demonstrated by the results obtained at each fermentation cycle (Table 2). These values are considered technically adequate for acetic acid fermentation. Silva et al. (2007) showed that $50 \mathrm{~h}$ was required to reach the maximum concentration of acetic acid from fermented cashews. Bortolini et al. (2001) obtained an oxidation time for ethanol from kiwi acetic acid of $12 \mathrm{~h}$ in a submerged process and $24 \mathrm{~h}$ for a generator process. Nanba et al. (1985) optimized the 
Spinosa et al.

Table 2. Monitoring acetic acid fermentation from rice wine conducted in an Acetator ${ }^{\circledR}$ autopilot $8 \mathrm{~L}$.

\begin{tabular}{|c|c|c|c|c|c|c|c|c|c|c|c|c|c|c|}
\hline \multirow{3}{*}{ Cycle } & \multicolumn{7}{|c|}{ Acetador } & \multicolumn{7}{|c|}{ Product } \\
\hline & ${ }^{a} \mathrm{t}$ & $\mathrm{T}$ & ${ }^{\mathrm{b}} \mathrm{Af}$ & ${ }^{\mathrm{c}} \mathrm{V}_{1}$ & ${ }^{\mathrm{d}} \mathrm{A}_{1}$ & ${ }^{e} \mathrm{E}_{1}$ & ${ }^{\mathrm{f}} \mathrm{TC}_{1}$ & ${ }^{8} V_{2}$ & $\mathrm{pH}$ & ${ }^{\mathrm{h}} \mathrm{A}_{2}$ & ${ }^{\mathrm{i}} \mathrm{E}_{2}$ & ${ }^{\mathrm{i}} \mathrm{TC}_{2}$ & ${ }^{\mathrm{k}} \eta_{\mathrm{aa}}$ & ${ }^{\mathrm{l}} \mathrm{P}_{\mathrm{aa}}$ \\
\hline & (h) & $\left({ }^{\circ} \mathrm{C}\right)$ & $(\mathrm{L} / \mathrm{h})$ & (L) & $(\%)$ & $(\%)$ & $(\%)$ & (L) & - & $(\%)$ & $(\%)$ & $(\%)$ & $(\%)$ & $(\mathrm{g} / \mathrm{L} / \mathrm{h})$ \\
\hline & & 24.3 & 22.0 & 5.0 & 5.3 & 3.2 & 8.4 & & & & & & & \\
\hline \multirow[t]{2}{*}{1} & 54.0 & & & & & & & 0.7 & 2.6 & 8.6 & 0.4 & 9.1 & 105.9 & 0.140 \\
\hline & & 26.2 & 30.0 & 5.9 & 6.3 & 1.4 & 7.7 & & & & & & & \\
\hline 2 & 34.0 & & & & & & & 2.3 & 2.6 & 7.8 & 0.3 & 8.1 & 95.1 & 0.656 \\
\hline 3 & & 28.3 & 35.0 & 6.1 & 4.7 & 2.6 & 7.3 & & & & & & & \\
\hline \multirow[t]{2}{*}{4} & 28.0 & & & & & & & 2.3 & 2.6 & 7.4 & 0.3 & 7.6 & 90.2 & 0.756 \\
\hline & & 29.3 & 30.0 & 5.8 & 5.4 & 1.8 & 7.2 & & & & & & & \\
\hline \multirow[t]{2}{*}{5} & 21.0 & & & & & & & 2.3 & 2.7 & 7.0 & 0.3 & 7.2 & 85.5 & 0.954 \\
\hline & & 30.2 & 30.0 & 6.0 & 5.4 & 1.8 & 7.2 & & & & & & & \\
\hline 7 & & 30.1 & 32.0 & 6.0 & 5.3 & 1.7 & 7.1 & & & & & & & \\
\hline \multirow[t]{2}{*}{8} & 40.5 & & & & & & & 2.3 & 2.7 & 7.0 & 0.2 & 7.2 & 86.1 & 0.498 \\
\hline & & 29.8 & 32.0 & 5.9 & 4.8 & 2.2 & 7.0 & & & & & & & \\
\hline \multirow[t]{2}{*}{9} & 30.0 & & & & & & & 2.3 & 2.7 & 6.8 & 0.3 & 7.1 & 83.7 & 0.655 \\
\hline & & 29.7 & 30.0 & 6.4 & 4.8 & 2.1 & 6.9 & & & & & & & \\
\hline 10 & 25.0 & & & & & & & 2.3 & 2.7 & 6.6 & 0.4 & 7.0 & 80.6 & 0.756 \\
\hline${ }^{\mathrm{m}}$ Average & $28.2 \pm 6.39$ & $28.7 \pm 1.70$ & $32.0 \pm 1.93$ & $6.03 \pm 0.17$ & $5.3 \pm 0.46$ & $2.0 \pm 0.34$ & $7.2 \pm 0.22$ & $2.3 \pm 0.0$ & $2.66 \pm 0.05$ & $7.1 \pm 0.35$ & $0.3 \pm 0.8$ & $7.4 \pm 0.35$ & $88.2 \pm 4.49$ & $0.73 \pm 0.14$ \\
\hline
\end{tabular}

process of slow fermentation for the production of vinegar and obtained $3 \%$ of acetic acid in the product, with a fermentation time of $100 \mathrm{~h}$.

Figures 3 and 4 present the results for the yield and productivity obtained in nine cycles from the second to the tenth fermentation cycle.

The converted amount of alcohol, with a concentration of $6.28 \%(\mathrm{w} / \mathrm{v})$ acetic acid, was in the range from 80.6 to $95.1 \%$, with an average over nine cycles of $88.2 \pm 4.49 \%$ and a coefficient of variation of 0.05 , obtained from the second to the tenth fermentation cycle. Bortolini et al. (2001) presented yields ranging from 93.24 to $98.34 \%$ for the submerged process and around $82.35 \%$ for the generator process, when kiwi wine was used with ethanol content between $3.54 \%$ and $9.61 \%(\mathrm{w} / \mathrm{v})$.

The productivity average of rice vinegar was $0.7 \pm 0.14 \mathrm{~g} / \mathrm{L} / \mathrm{h}$ of acetic acid. Silva et al. (2007), when investigating the production of cashew vinegar, obtained a productivity of $0.55 \mathrm{~g} / \mathrm{L} / \mathrm{h}$. The authors started from syrup with an initial total concentration of $5.8 \%$ (4.5\% ethanol and $1.0 \%$ acetic acid in cashew wine). Bortolini et al. (2001) compared the submerged and generator processes, and obtained productivity values of 0.29 to $1.73 \mathrm{~g} / \mathrm{L} / \mathrm{h}$, respectively. Zancanaro (1988), studying the optimization of the slow process of acetic fermentation, reported that this process can achieve a productivity of $0.038 \mathrm{~g} / \mathrm{L} / \mathrm{h}$ for acetic acid, if the recommendations advocated in his study are followed. Despite the differences between the slow and submerged processes, and comparing the data obtained from both, there is far greater productivity with the submerged process in relation to the slow or generator process.

The efficiency of the submerged process is directly linked to the oxygenation of the medium and the state of division of the air bubbles. The Acetator ${ }^{\circledR}$ autopilot allowed for achieving the reported results. The most important component of the reactor was the aeration system. With the pressure exerted by the rotation of the turbine, the aerator inhaled ambient air. This, in turn, was filtered before passing through the suction tube and be introduced, in a downward motion, into the stator, then blended with the liquid contained within the vessel.

The aeration system enabled the production of air microbubbles, with a diameter of 1 to $2 \mathrm{~mm}$ and flow rates of 0.3 to 0.4 volumes of air per volume of medium per minute. The microbubbles were introduced into the bottom of the fermenter by means of aerating turbines causing intense agitation in the medium. The retention time was optimized, since the microbubbles tended to rise more slowly than the larger bubbles. Thus, an excellent dissolved oxygen profile was produced in the fermenter. Microbubbles have greater surface contact with the liquid, reaching in situations of homogeneous fermentation, without turbulence or dead zones, a value of up to $80 \%$ dissolved oxygen. Another important factor during the fermentation process is that air consumption is minimized, since it reduces the loss of raw materials by evaporation and prevents the formation of foam, providing a stable fermentation medium (Schlepütz et al., 2013; Qi et al., 2014). 


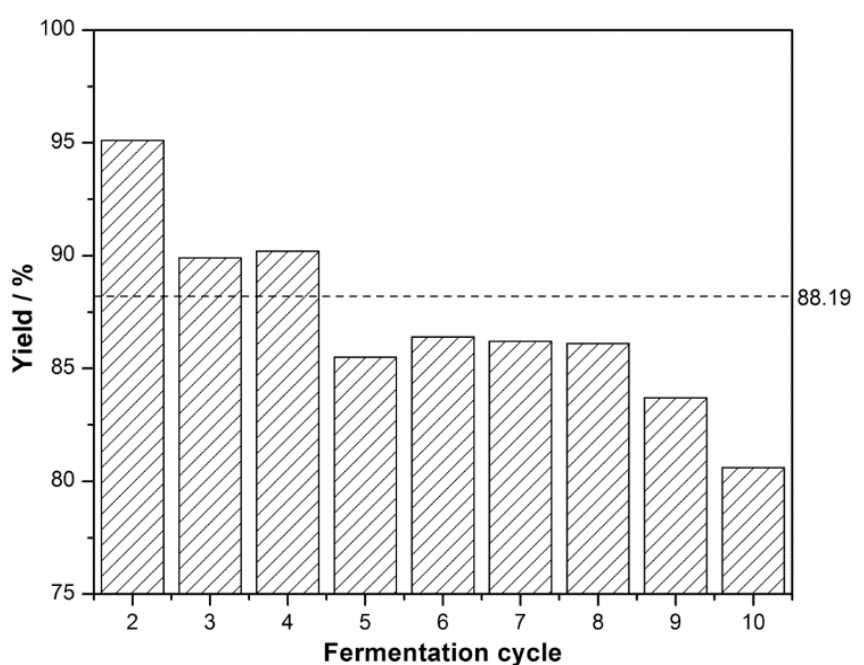

Figure 3. Conversion efficiency of rice wine to rice vinegar conducted in the Acetator ${ }^{\circledR}$.

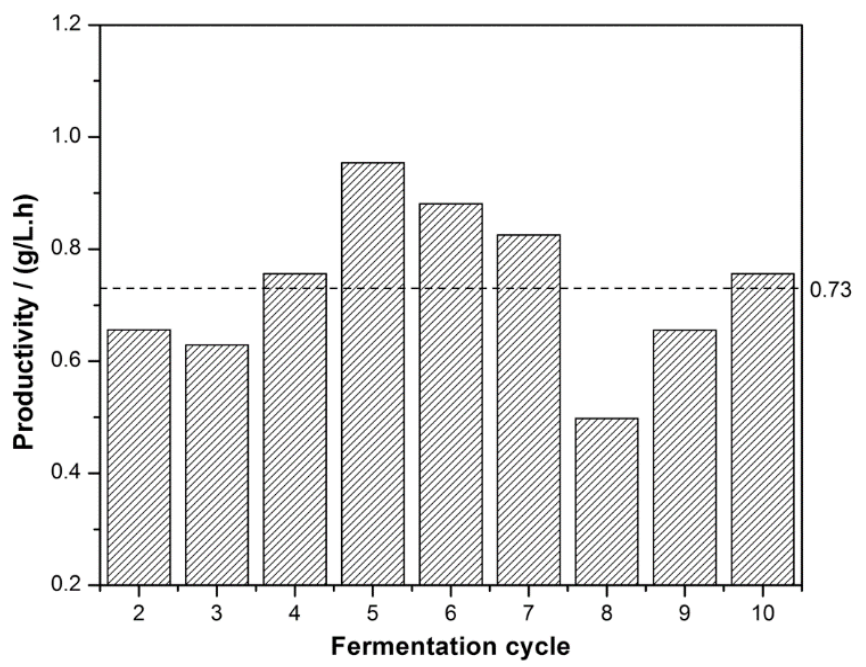

Figure 4. Productivity of rice vinegar conducted in Acetator ${ }^{\circledR}$.

The product of acetic acid fermentation (vinegar) was clear and had no deposits. The results obtained from the evaluation of the quality and identity of rice vinegar are shown in Table 3.

Brazilian law does not have standards for the identity and quality of rice vinegar; regulations only exist for wine vinegars, fruit, cereal alcohol and alcohol. Based on the quality standards required for the types of vinegars mentioned, the rice vinegar produced in this study is in accordance with such norms. The main standard of quality is the content of acetic acid (Brasil, 2012). Acidity by itself determines if the product is a vinegar or diluted acetic acid. Several tests have been proposed, but have high cost. A simple method, not yet fully reliable, is the measurement of $\mathrm{pH}$. Non-volatile buffering substances have higher $\mathrm{pH}$ values than those observed in acetic acid solutions with equivalent concentrations (Adams, 1998).

Table 4 shows the composition of organic acids present in the vinegar.
Table 3. Composition of rice vinegar.

\begin{tabular}{ccc}
\hline Components & $\%(\mathrm{w} / \mathrm{v})$ \\
\hline Acidity & 6.85 \\
& Ethyl alcohol & $0.17^{\mathrm{a}}$ \\
& Minerals & 1.26 \\
& Dry extract & 1.78 \\
\hline${ }^{\mathrm{a}(\mathrm{w} / \mathrm{w})}$ & &
\end{tabular}

Table 4. Composition of organic acids present in rice vinegar.

\begin{tabular}{cc}
\hline Components & $\mathrm{mg} / \mathrm{L}$ \\
\hline Acetic acid & 61500 \\
Cis-aconitic acid & 6 \\
Maleic acid & 3 \\
Trans-aconitic acid & 3 \\
Succinic+shikimic acids & 4 \\
Lactic acid & 300 \\
Formic acid & 180 \\
Oxalic acid & 3 \\
Fumaric acid & 3 \\
Itaconic acid & 1 \\
\hline
\end{tabular}

The secondary constituents of vinegar are important because of their contributions to flavor and aroma. These components are characteristic of each substrate used in alcoholic and acetic fermentation. With aging, the vinegar becomes softer and more pleasant to taste and smell, due to reactions such as esterification. These esterification reactions remove the acids and alcoholic groups from the medium, providing aromatic esters, and oxidation oxidizes aldehyde groups, conferring ruggedness to the vinegar (Reddy et al., 2008; Adams, 1998).

\section{Conclusion}

The results obtained under the experimental conditions and with the equipment described above provided vinegar from rice wine, with a productivity of $0.7 \mathrm{~g} / \mathrm{L} / \mathrm{h}, 88.2 \%$ yield and $7.1 \%$ total acidity $(\mathrm{w} / \mathrm{v})$ in acetic acid; the average was evaluated over nine fermentation cycles. The Acetator ${ }^{\circledR}$ autopilot contributed decisively to the final results regarding productivity and the acetic acid content. The product of acetic acid fermentation (vinegar) was clear and showed no deposits due to the tangential microfiltration equipment used.

\section{Acknowledgements}

The authors thank the State University of Londrina (UEL), $\mathrm{CNPq}$ for a scholarship as well as Gerhard Feigl and Frings Microdyn from Brazil.

\section{References}

Adams, M. R. (1998). Vinegar. In B. J. B. Wood (Ed.), Microbiology of fermented foods (Vol. 1, pp. 1-44). London: Elsevier Applied Science.

Adams, M. R., \& Moss, M. O. (2008). Fermented and microbial foods. In M. R. Adams \& M. O. Moss (Eds.), Food microbiology (Vol. 1, pp. 310-369). Cambridge: The Royal Society of Chemistry. 
Baena-Ruano, S., Jiménez-Ot, C., Santos-Dueñas, I. M., CanteroMoreno, D., Barja, F., \& García-García, I. (2006). Rapid method for total, viable and non-viable acetic acid bacteria determination during acetification process. Process Biochemistry, 41(5), 1160-1164. http://dx.doi.org/10.1016/j.procbio.2005.12.016.

Blankart, C. B. (2013). Oil and vinegar: a positive fiscal theory of the euro crisis. Kyklos, 66(4), 497-528. http://dx.doi.org/10.1111/kykl.12033.

Bortolini, F., Sant'anna, E. S., \& Torres, R. C. (2001). Behavior of alcoholic and acetic fermentations of kiwi mashes (Actinidia deliciosa); composition of mashes and production methods. Food Science and Technology (Campinas), 21(2), 236-243. http://dx.doi.org/10.1590/ S0101-20612001000200020.

Brasil, Ministério da Agricultura, Pecuária e Abastecimento. (2005). Manual operacional de bebidas e vinagres (Instrução Normativa no. 24, de 8 de setembro de 2005). Diário Oficial da República Federal do Brasil.

Brasil, Ministério da Agricultura, Pecuária e Abastecimento. (2012). Estabelece os padrões de identidade e qualidade e a classificação dos fermentados acéticos (Instrução Normativa no. 6, de 3 de abril de 2012). Diário Oficial da República Federal do Brasil.

Brasil, Ministério da Agricultura, Pecuária e Abastecimento. (2009). Regulamenta a Lei no 8.918, de 14 de julho de 1994, que dispóe sobre a padronização, a classificação, o registro, a inspeção, a produção e a fiscalização de bebidas (Decreto no. 6.871, de 4 de junho de 2009). Diário Oficial da República Federal do Brasil.

Budak, N. H., Aykin, E., Seydim, A. C., Greene, A. K., \& Guzel-Seydim, Z. B. (2014). Functional properties of vinegar. Journal of Food Science, 79(5), R757-R764. http://dx.doi.org/10.1111/1750-3841.12434. PMid:24811350

Chen, C., \& Chen, F. (2009). Study on the conditions to brew rice vinegar with high content of $\gamma$-amino butyric acid by response surface methodology. Food and Bioproducts Processing, 87(4), 334340. http://dx.doi.org/10.1016/j.fbp.2009.03.003.

Chen, Q., Ding, J., Cai, J., Sun, Z., \& Zhao, J. (2012). Simultaneous measurement of total acid content and soluble salt-free solids content in Chinese vinegar using near-infrared spectroscopy. Journal of Food Science, 77(2), C222-C227. http://dx.doi.org/10.1111/j.17503841.2011.02549.x. PMid:22250960

Clarke, R. J., \& Bakker, J. (2008). Wine: flavour chemistry (2nd ed.). Oxford: Wiley-Blackwell.

Dato, M. A. F., Pizauro Junior, J. M., \& Mutton, M. J. R. (2005). Analysis of the secondary compounds produced by Saccharomyces cerevisiae and wild yeast strains during the production of "cachaça". Brazilian Journal of Microbiology, 36(1), 70-74. http://dx.doi.org/10.1590/ S1517-83822005000100014.

Fan, J., Zhang, Y., Chang, X., Zhang, B., Jiang, D., Saito, M., \& Li, Z. (2009). Antithrombotic and fibrinolytic activities of methanolic extract of aged sorghum vinegar. Journal of Agricultural and Food Chemistry, 57(18), 8683-8687. http://dx.doi.org/10.1021/jf901680y. PMid:19754177

Fortes, G. A. C., Naves, S. S., Ferri, P. H., \& Santos, S. C. (2012). Evaluation of chemical changes during Myrciaria cauliflora (jabuticaba fruit) fermentation by ${ }^{1} \mathrm{H}$ NMR spectroscopy and chemometric analyses. Journal of the Brazilian Chemical Society, 23(10), 1815-1822. http:// dx.doi.org/10.1590/S0103-50532012005000050.

Haruta, S., Ueno, S., Egawa, I., Hashiguchi, K., Fujii, A., Nagano, M., Ishii, M., \& Igarashi, Y. (2006). Succession of bacterial and fungal communities during a traditional pot fermentation of rice vinegar assessed by PCR-mediated denaturing gradient gel electrophoresis. International Journal of Food Microbiology, 109(1-2), 79-87. http:// dx.doi.org/10.1016/j.ijfoodmicro.2006.01.015. PMid:16499984

Mas, A., Torija, M. J., García-Parrilla Mdel, C., \& Troncoso, A. M. (2014). Acetic acid bacteria and the production and quality of wine vinegar. Scientific World Journal, 2014(1), 394671. http://dx.doi. org/10.1155/2014/394671. PMid:24574887.

Moretto, E. (1988). Vinhos \& vinagres: processamento e análises. Florianópolis: Editora UFSC.

Nakamura, K., Ogasawara, Y., Endou, K., Fujimori, S., Koyama, M., \& Akano, H. (2010). Phenolic compounds responsible for the superoxide dismutase-like activity in high-Brix apple vinegar. Journal of Agricultural and Food Chemistry, 58(18), 10124-10132. http://dx.doi.org/10.1021/jf100054n. PMid:20795622

Nanba, A., Kimura, K., \& Nagai, S. (1985). Vinegar production by Acetobacter rancens cells fixed on a hollow fiber module. Journal of Fermentation Technology, 63(2), 175-179.

Qi, Z., Yang, H., Xia, X., Quan, W., Wang, W., \& Yu, X. (2014). Achieving high strength vinegar fermentation via regulating cellular growth status and aeration strategy. Process Biochemistry, 49(7), 1063-1070. http://dx.doi.org/10.1016/j.procbio.2014.03.018.

Qiu, J., Ren, C., Fan, J., \& Li, Z. (2010). Antioxidant activities of aged oat vinegar in vitro and in mouse serum and liver. Journal of the Science of Food and Agriculture, 90(11), 1951-1958. http://dx.doi. org/10.1002/jsfa.4040. PMid:20564418.

Reddy, L. V., Reddy, Y. H. K., Reddy, L. P. A., \& Reddy, O. V. S. (2008). Wine production by novel yeast biocatalyst prepared by immobilization on watermelon (Citrullus vulgaris) rind pieces and characterization of volatile compounds. Process Biochemistry, 43(7), 748-752. http:// dx.doi.org/10.1016/j.procbio.2008.02.020.

Rizzon, L. A., \& Miele, A. (1998). Características analíticas de vinagres comerciais de vinhos brasileiros. Brazilian Journal of Food Technology, 1(1-2), 25-31.

Schlepütz, T., Gerhards, J. P., \& Büchs, J. (2013). Ensuring constant oxygen supply during inoculation is essential to obtain reproducible results with obligatory aerobic acetic acid bacteria in vinegar production. Process Biochemistry, 48(3), 398-405. http://dx.doi.org/10.1016/j. procbio.2013.01.009.

Silva, M. E., Torres Neto, A. B., Silva, W. B., Silva, F. L. H., \& Swarnakar, R. (2007). Cashew wine vinegar production: alcoholic and acetic fermentation. Brazilian Journal of Chemical Engineering, 24(2), 163-169. http://dx.doi.org/10.1590/S0104-66322007000200001.

Solieri, L., \& Giudici, P. (2009). Vinegars of the world. Berlin: Springer.

Tessaro, D., Larsen, A. C., Dallago, R. C., Damasceno, S. G., Sene, L., \& Coelho, S. R. M. (2010). Alcohol and acetic fermentation appraisal for vinegar production from orange juice. Acta Scientiarum Technology, 32(2), 201-205. http://dx.doi.org/10.4025/actascitechnol.v32i2.4275.

Xiao, Z., Dai, S., Niu, Y., Yu, H., Zhu, J., Tian, H., \& Gu, Y. (2011). Discrimination of Chinese vinegars based on headspace solid-phase microextraction-gas chromatography mass spectrometry of volatile compounds and multivariate analysis. Journal of Food Science, 76(8), C1125-C1135. http://dx.doi.org/10.1111/j.1750-3841.2011.02356.x. PMid:22417575

Zancanaro, O., Jr. (1988). Otimização do processo lento de fermentação acética (Tese de doutorado). Universidade de São Paulo, São Paulo. 